\title{
Rooting biostimulants for Coffea arabica L. cuttings
}

\author{
Harianna Paula Alves de Azevedo' (iD), Alex Mendonça de Carvalho², Douglas Alves Vidal' (iD), \\ Heloisa Oliveira dos Santos ${ }^{1}$ (iD), Joyce Doria' ${ }^{1}$ (iD)
}

${ }^{1}$ Universidade Federal de Lavras/UFLA, Departamento de Agricultura/DAG, Lavras, MG, Brasil

${ }^{2}$ Universidade Estadual Paulista Júlio de Mesquita Filho/UNESP, Registro, SP, Brasil

Contact authors: harianna_tp@hotmail.com, joyce.doria@ufla.br, douglas.alvesv@hotmail.com, heloisa.osantos@ufla.br, alex.carvalho@unesp.br

Received in October 5, 2019 and approved in March 10, 2020

\begin{abstract}
In the rooting process of Arabica coffee cuttings, plant hormones are used for inducing root formation. However, synthetic molecules cannot be used to form organic seedlings. The objective of this work was to evaluate the effect Cyperus haspan extract and different concentrations and types of humic substances on Arabica coffee cuttings. Arabica coffee shoots were collected, and cuttings containing at least two buds were taken. The experiment had a three-factor design, 2 (presence or absence Cyperus haspan extract) $\times 2$ (humic or fulvic acid) $\times 4$ ( $0,10,25$ and 50 mg dm ${ }^{-3}$ concentrations). The following vegetative data were evaluated: shoot height $(\mathrm{cm})$, survival, remaining leaves, leaf pairs, vigor, number of shoots, root length, area root, volume root, diameter root and fresh and dry mass were also evaluated. The enzyme activity of H+-ATPase, catalase, superoxide dismutase, alcohol dehydrogenase and esterase was also quantified. The results showed that the Arabica coffee cutting rooting rate was increased when treated with humic acid at a concentration of $10 \mathrm{mg} \mathrm{dm}^{-3}$ in the presence of Cyperus haspan extract. The lowest oxidative stress was observed in the $10 \mathrm{mg}$. $\mathrm{dm}^{-}{ }^{3}$ humic and fulvic acid treatments, regardless of the use of the extract.
\end{abstract}

Key words: Root system; IBA; humic acid; fulvic acid; shoots.

\section{INTRODUCTION}

Arabica coffee is entirely propagated via seeds since it is a crop with approximately $90 \%$ autogamy. Because it is a perennial crop, healthy and well-developed seedlings are vital for the successful establishment of new crops.

The number of studies on the vegetative propagation of Arabica coffee cuttings has increased recently (Pereira et al., 2018; Rezende et al., 2017), but this method is still little used due to the difficulty of establishing a standardized methodology because there is a large variation among the cultivars in how they respond to the rooting process (Carvalho, 2008).

The current methodologies used for the rooting of Arabica coffee cuttings use auxins for inducing root formation, and these cuttings activate vascular cambium cells to promote the formation of adventitious roots in the cuttings (Hartmann et al., 2011). IBA (indole-3-butyric acid) is a auxin growth regulator group, have been preferentially used because they are nontoxic and are the most effective for most species. However, synthetic molecules cannot be used for forming organic seedlings.

In the context of organic agriculture it is necessary to find alternatives to promote rooting. Cyperus haspan, considered the most important weed worldwide, is known for its allelopathic effects (Andrade; Bittencourt; Vestena, 2009). According to Lorenzi (2000), C. haspan has high level of IBA hormone, specific for plant root formation. IBA has been widely used to stimulate the rooting of cuttings of several species (Cruz Silva; Alves Neto; Viecelli, 2011). These authors have reported that Cyperus haspan tubers contain a greater amount of auxins, like IBA, than any other herbaceous species.

An interesting alternative for promoting the rooting of coffee cuttings is the use of humic substances (HS). Humic substances are present in the decomposed organic fraction in the soil. They may have similar effects to auxins on plant metabolism. For example, the development of lateral roots is increased upon treatment with humic substances and is related to the cell division mechanisms regulated by auxins (Trevisan et al., 2010). Moreover, they are able to induce the exudation of several of chemical compounds in the root region, they also influence the size and structure of the microbial community, having an important role in plant nutrition (Canellas, 2019).

The aim of this study was to evaluate the effect of Cyperus haspan extract and different concentrations and types of humic substances in the rooting of Arabica coffee cuttings to enable the production of clonal seedlings for organic crops.

\section{MATERIAL AND METHODS}

The experiment was conducted at the Federal University of Lavras in the municipality of Lavras, Minas Gerais at the Department of Agriculture, Coffee Farming Sector where shoots (suckers) of Arabica coffee plants, cultivar Topázio MG1190, were collected. After the shoots were collected, 5 to $7 \mathrm{~cm}$ cuttings were taken that contained at least two buds; a pair of leaves was left on each cutting, which was then washed in pure water (Oliveira et al., 2010). 
The cuttings were treated with Cyperus haspan extract by dipping their bases in the extract solution for 60 minutes and were then placed in substrate for rooting. The Cyperus haspan was made with $800 \mathrm{~g}$ of plant tubers collected at the Universidade Federal de Lavras campus according to the methodology proposed in Dias et al. (2012). The extract was prepared by grinding the tubers and dissolving them in a solution composed of $665 \mathrm{~mL}$ of distilled water and $335 \mathrm{~mL}$ of grain alcohol (Roncatto et al., 2008).

The humic substances were placed in the substrate (2:2:1 sand, clay, vermiculite) via water at a concentration of $0,10,25$ and $50 \mathrm{mg} \mathrm{dm}^{-3}$. The experiment was carried out in a greenhouse that had controlled relative air humidity (between $85-90 \%)$ and temperature $\left(24{ }^{\circ} \mathrm{C}\right)$, with $50 \%$ shade cloth roofing and irrigation by an automated mist microsprinkler system.

At the end of the experiment (at 130 days) the following vegetative data were evaluated: shoot height $(\mathrm{cm})$, survival, remaining leaves, leaf pairs, vigor and number of shoots. The root length, area, volume and diameter were also evaluated, and the fresh and dry root masses were quantified. The enzyme activities of $\mathrm{H}+$-ATPase and the antioxidant enzymes catalase (CAT), superoxide dismutase (SOD), alcohol dehydrogenase $(\mathrm{ADH})$ and esterase (EST) were also quantified.

To analyze the length, area, volume and diameter of the root, photographs of the cuttings were taken for analysis in the software SAFIRA, 2010 - Fiber and Root Analysis System (Jorge; Rodrigues, 2010). The vegetative data were analyzed by counting and measuring with centimeter rulers. The roots samples were washed and then weighed on an analytical balance to obtain the fresh mass. After weighing the samples, they were placed individually in labeled paper bags and placed in a forcedair oven at $65^{\circ} \mathrm{C}$ where they remained until reaching a constant weight, after which they were weighed on an analytical balance to obtain the dry mass. The leaves were removed and stored at $-80{ }^{\circ} \mathrm{C}$ for further evaluation of enzyme activity.

The Arabica coffee seedlings were macerated in polyvinylpyrrolidone (PVP) and liquid nitrogen. Afterwards, $100 \mathrm{mg}$ samples were collected for analysis of each enzyme and stored in microtubes at $-86^{\circ} \mathrm{C}$.

The CAT activity was analyzed using a reaction medium consisting of $200 \mathrm{mM}$ potassium phosphate ( $\mathrm{pH} 7.0)$, water and $250 \mathrm{mM} \mathrm{H} 2 \mathrm{O} 2$, which was then incubated at 30 ${ }^{\circ} \mathrm{C}$ while the hydrogen peroxide consumption was monitored (Havir; Mc Hale, 1987).

For SOD activity analysis, the reaction medium consisted of $100 \mathrm{mM}$ potassium phosphate $(\mathrm{pH} 7.8), 70 \mathrm{mM}$ methionine, $10 \mu \mathrm{M}$ EDTA, water, $1 \mathrm{mM}$ nitrotetrazolium blue (NBT) and $0.2 \mathrm{mM}$ riboflavin. The cuvette containing the reaction medium and sample was illuminated for 7 minutes. For the control, the same reaction medium without sample was illuminated, while the blank was kept in the dark. SOD was assessed by the ability of the enzyme to inhibit NBT photoreduction. The readings were carried out at $560 \mathrm{~nm}$, considering that one unit of SOD corresponded to the amount of enzyme capable of $50 \%$ inhibition of NBT photoreduction under the assay conditions (Giannopolitis et al., 1977).

For $\mathrm{ADH}$ assessment, $250 \mu \mathrm{L}$ of extraction buffer (0.2 M Tris-HCl, $\mathrm{pH} 8.0$ ) and $0.1 \% \beta$-mercaptophenol were added. The samples were left overnight and were subsequently centrifuged at $14,000 \mathrm{rpm}$ for 30 minutes at $4{ }^{\circ} \mathrm{C}$. A $60 \mu \mathrm{L}$ aliquot of supernatant was collected and applied to a $7.5 \%$ polyacrylamide separating gel with a $4.5 \%$ stacking gel. The electrophoresis was performed at 150 volts for 6 hours, upon which the gels were stained according to the methodology described by Alfenas (2006).

For EST assessment, protein extraction was performed by adding $320 \mu \mathrm{L}$ of extraction buffer ( $0.2 \mathrm{M}$ Tris) to 100 $\mathrm{mg}$ of seed powder, vortexing and storing for one hour in a refrigerator. The samples were centrifuged at $16,000 \mathrm{rpm}$ at $4{ }^{\circ} \mathrm{C}$ for 60 minutes, and $60 \mu \mathrm{L}$ of the supernatant was applied to a polyacrylamide gel. A Tris-glycine ( $\mathrm{pH} 8.9)$ gel/electrode buffer system was used. Electrophoresis was performed at 110 $\mathrm{V}$ for 5 hours, and the gels were stained for esterase activity, as described by Alfenas (2006). The interpretation of the results was based on a visual analysis of the electrophoresis gels, taking into consideration the intensity of each of the electrophoretic bands in the evaluated system.

For analysis of the H+-ATPase enzyme, the macerated samples were homogenized in $20 \mathrm{~mL}$ of ice-cold extraction medium containing $250 \mathrm{mmol} \mathrm{L}^{-1}$ sucrose, $10 \%$ glycerol (w:v), $0.5 \%$ PVP-40 (polyvinylpyrrolidone- $40 \mathrm{kDa}$ ), $2 \mathrm{mmol} \mathrm{L}^{-1}$ EDTA, $0.2 \%$ BSA (bovine serum albumin) (w:v) and $0.1 \mathrm{M}$ Tris- $\mathrm{HCl}$, $\mathrm{pH}$ 7.5. The total protein concentration in the preparation was measured by the method in Bradford (1976).

The reaction was initiated with the addition of the protein (present in isolated vesicles) and stopped by adding trichloroacetic acid (TCA) to a final concentration of $10 \%$ (v:v).

A randomized block design with 4 replicates and 5 cuttings per plot was used. The experiment had a three-factor design, 2 (presence or absence Cyperus haspan extract) x 2 (humic or fulvic acid) $\mathrm{x} 4\left(0,10,25\right.$ and $\left.50 \mathrm{mg} \mathrm{dm}^{-3}\right)$, that is, 16 treatments and 64 plots with total use of 320 cuttings. Analysis of variance was performed for all of the evaluated characteristics, and when significant, qualitative variables were analyzed by the Scott-Knott test at 5\% and quantitative variables by regression analysis. The SISVAR software was used for the analyses (Ferreira, 2014).

\section{RESULTS AND DISCUSSION}

In the analysis of variance there was no significant effect found for the studied sources regarding survival, vigor, 
root length, root area and root volume. However, for the number of shoots, shoot height and number of leaf pairs there was a significant effect at the 5\% significance level for the factor concentrations of humic substances. For the remaining leaves, there was a significant effect of the interaction between the concentrations and the types of humic substances.

There was a triple interaction for the characteristics of fresh and dry root mass, $\mathrm{H}^{+}$-ATPase activity and antioxidant enzymes, that is, there were changes in the behavior of these variables in the presence and absence of Cyperus haspan extract with the increase of the concentration of humic substances.

The shoot height and number of shoots showed similar curves with increasing concentrations of humic substances. Peaks were obtained at the highest and lowest concentrations $\left(0\right.$ and $\left.50 \mathrm{mg} \mathrm{dm}^{-3}\right)$ (Figure 1). The promotion of plant growth by humic substances is well documented (Nardi et al., 2009). In general, the growth response of monocotyledons to HS appears to be higher than that of dicotyledons, although the molecular and physiological basis for this difference remains obscure (Canellas et al., 2011).

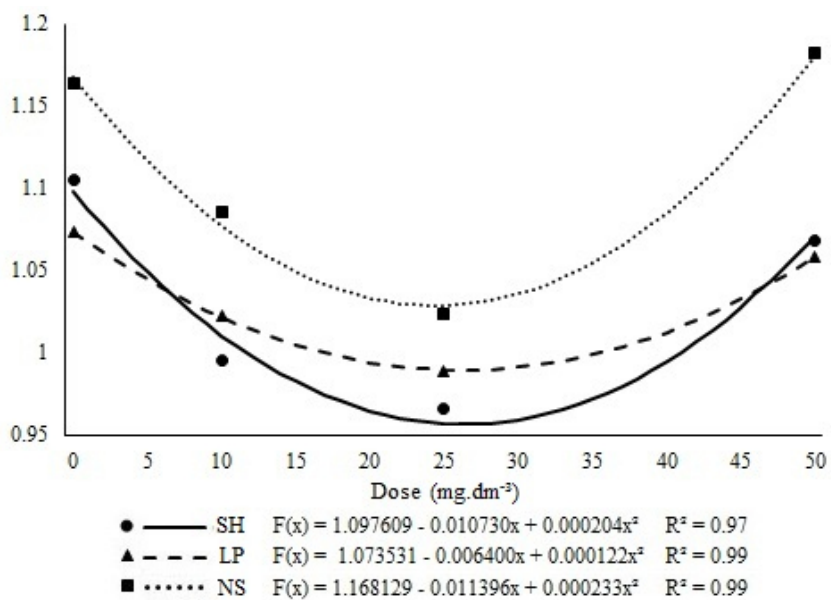

Figure 1: Shoot height (SH) in centimeters, number of leaf pairs (LP) and number ofshoots (NS) according to humic concentrations.

However, in the case of Arabica coffee, the response of the shoots was not favorable to the use of these substances, one hypothesis to explain these results would be that the plant under stress, is induced to the production of hormones, which in the case of stress such as cutting, would be the production of auxins, which regulate the rooting and emission of shoots (Hartmann et al., 2011). By starting to add humic substances to the substrate, it signaled to the plant that it would not need the production of these hormones, but the concentrations were still low, not inducing buds. Adding higher doses of humic substances to the substrate consequently increased the auxin doses, thus leading to increased size and number of shoots (Geiss; Gutierrez; Bellini, 2009).
It was observed that for shoot height, number of leaves and number of shoots there was a decreasing behavior up to the $25 \mathrm{mg} \mathrm{dm}^{-3}$ dose of humic substances and from that dose there was a vegetative increment with linear response as it increases the dosages of humic substances. When analyzing the development with increasing concentrations of humic acid, the number of remaining leaves presented higher values at a concentration of approximately $40 \mathrm{mg} \mathrm{dm}^{-3}$ (Figure 2).

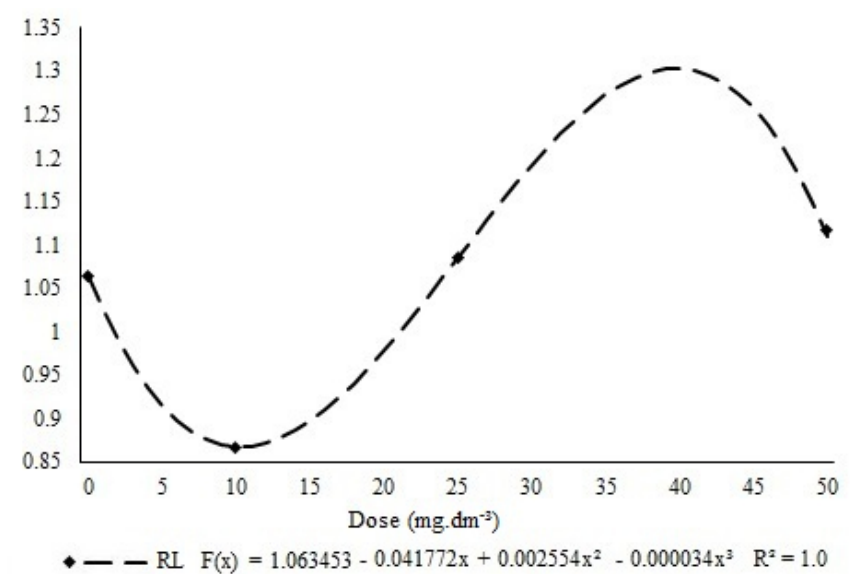

Figure 2: Number of remaining leaves $(R L)$ as a function of the humic acid concentration.

Leaves are essential for the rooting of cuttings because the metabolites generated by photosynthesis, together with the auxins, are of vital importance for root formation (Van Overbeek et al., 1946). Ferreira et al. (2008) stated that sprouting before rooting can be harmful to plants, but if the opposite occurs-if roots are first formed followed by sprouting-it can indicate that the cutting will be able to form a new plant. The remaining pair of leaves is expected to assist in this balance between the shoot and the root until new leaves are formed.

The mean diameter of the roots was higher in the presence of humic acid. However, for root diameter, the finer roots with smaller diameters had a greater nutrient uptake efficiency; in this case fulvic acid was better.

The mean dry mass of the root system was higher when fulvic acid was used. The dry matter data are important for growth analysis because they can be used to compare several factors under study in different situations. The $\mathrm{H}+-$ ATPase enzyme activity was higher when humic acid was applied to the substrate. The enzyme $\mathrm{H}+$-ATPase, which is also a proton pump, is active in the plasma membrane and is involved in the uptake of nutrients, creating a driving force for the ions to move across the membrane. By increasing its activity, nutrient use can also be increased, affecting not only the root system but also the development of the whole plant (Trevisan et al., 2010). The effects of HS on plant physiology include the promotion of root growth (Nardi et al., 2009). 
The fresh and dry mass of the roots varied with increasing concentration, type of acid and the presence or absence of Cyperus haspan extract. When using humic acid without Cyperus haspan extract, both the fresh and dry mass showed a peak at the $10 \mathrm{mg} \mathrm{dm}^{-3}$ concentration (Figure 3A). When Cyperus haspan extract was added to the treatment, only the fresh mass was shown to be significant, increasing with increasing extract concentration (Figure 3B). When fulvic acid was used without the Cyperus haspan extract, the fresh mass showed two peaks (at 10 and $50 \mathrm{mg} \mathrm{dm}^{-3}$ ), while the dry mass varied little, with a peak at the $10 \mathrm{mg} \mathrm{dm}^{-3}$ concentration (Figure 4A). When using the Cyperus haspan extract in combination with fulvic acid, the fresh mass also had a peak at the $10 \mathrm{mg} \mathrm{dm}^{-3}$ concentration, and the dry mass increased after $40 \mathrm{mg} \mathrm{dm}^{-3}$ (Figure 4B). The Cyperus haspan extract had a stronger effect when the substrate was treated with humic acid rather than fulvic acid, which may be due to the combined effect of the auxins present in both the humic acid and extract. Morard et al. (2011) found satisfactory responses in cucumber, maize, pelargonium and wheat when analyzing the effect of humic substances on the fresh mass of roots and on other parts of the plants, and they observed a biostimulating effect from these substances.

According to Casimiro et al. (2003), the increase in the number of roots is linked to the action of auxins on the target cells, which resume cell differentiation activities. Therefore, it can be inferred that the concentration of auxins in the natural Cyperus haspan extract is not high enough to increase the number of roots.

When using humic acid, the $\mathrm{H}^{+}$-ATPase activity increased linearly with increasing humic acid concentration. For fulvic acid, the increase followed a quadratic behavior and the relationship with increasing dose was not as strong, in addition to declining after a certain point (Figure 7). Promotion of the $\mathrm{H}^{+}$-ATPase enzyme activity could also promote the development of the root system. $\mathrm{H}^{+}$-ATPase is more commonly known as a proton pump and is primarily responsible for the uptake of nutrients by the roots, generating an electrochemical gradient that induces the transport of nutrients across the membrane of the root cells.
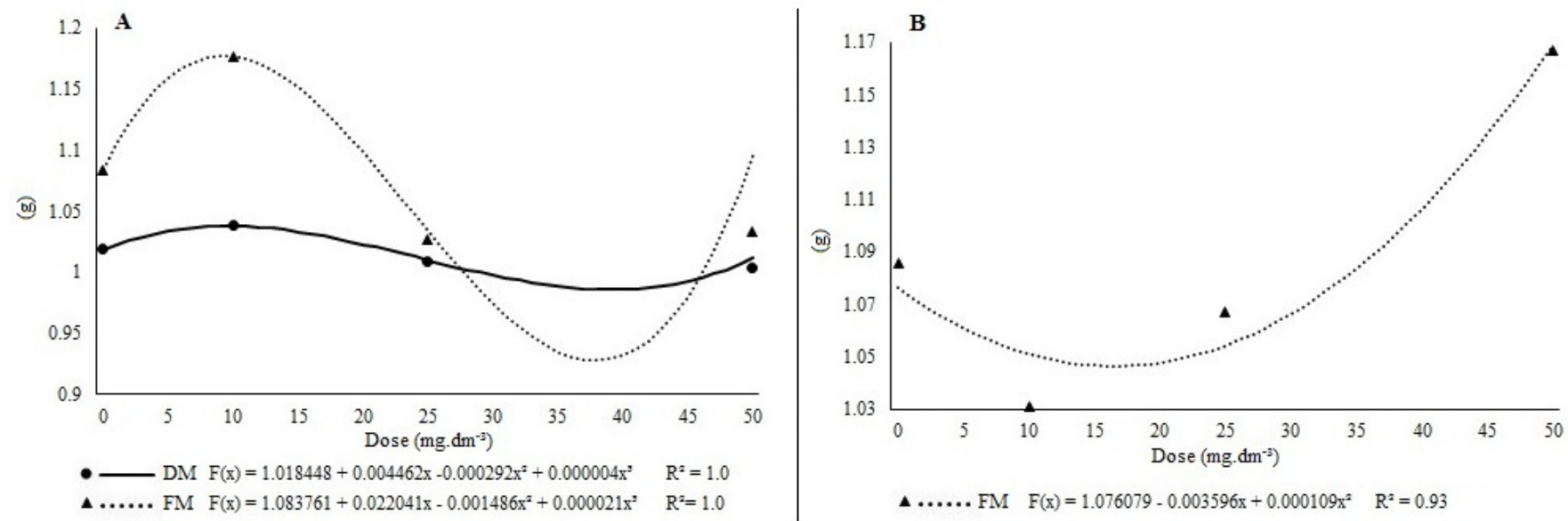

Figure 3: Dry mass (DM) and fresh mass (FM) of the root, expressed in grams, as a function of humic acid concentration in absence $(\mathrm{A})$ and presence Cyperus haspan extract $(\mathrm{B})$.
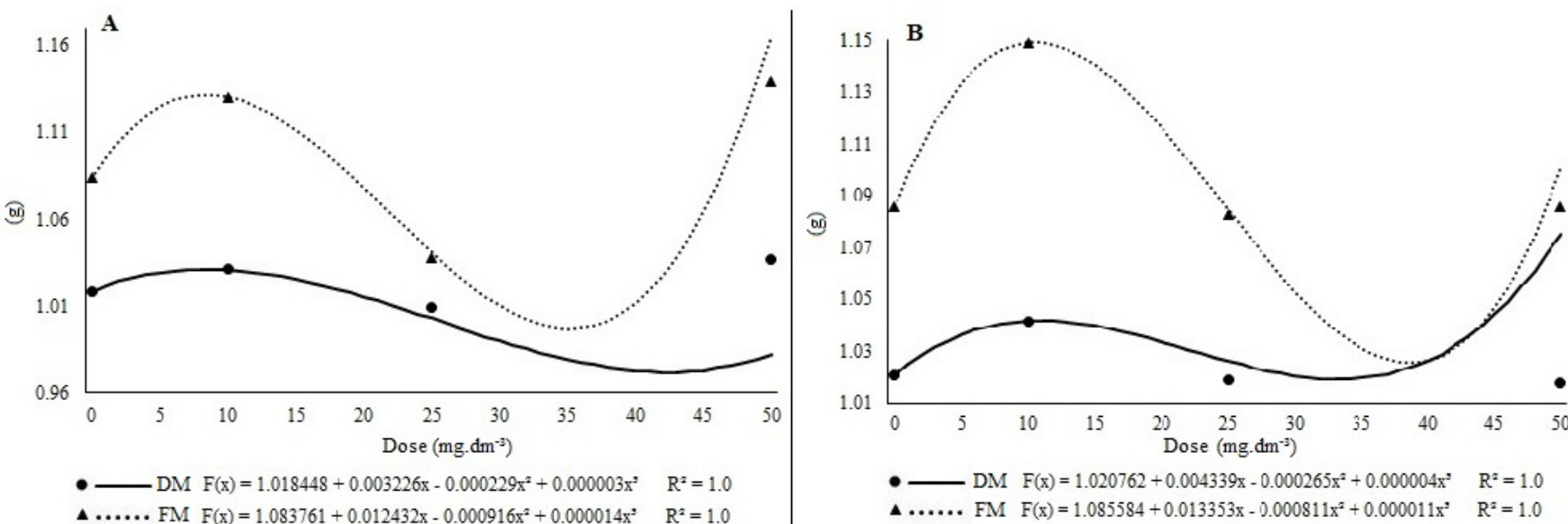

Figure 4: Dry mass (DM) and fresh mass (FM) of the root, expressed in grams, as a function of fulvic acid concentration in absence $(A)$ and presence $C$. haspan extract $(B)$. 
In the case of Arabica coffee, the enzyme activity was increased but had no effect on the roots. Indicating that not necessarily the increase in root length or root mass will reflect better nutrient utilization, as happens when $\mathrm{H}^{+}$-ATPase activity is increased, since the activation of this proton pump is decisive in the transport of nutrients through the membranes of the roots. cells (Palmgren, 2001). $\mathrm{H}^{+}$-ATPase is the main ally to nutrient uptake and utilization, so by interacting with the biostimulant effects of humic substances, plants improve nutrient uptake with increasing enzyme (Canellas et al., 2009; Jindo et al., 2012; Pinton et al., 1999).

When using $10 \mathrm{mg} \mathrm{dm}^{-3}$ of humic substance, the fresh mass had higher mean values in the absence of Cyperus haspan extract, whereas at the 25 and $50 \mathrm{mg} / \mathrm{dm}^{3}$ concentrations the mean values were higher in the presence of the extract. The mean $\mathrm{H}+$-ATPase enzyme activity was higher when the extract used at 10 and $25 \mathrm{mg} \mathrm{dm}^{-3}$, whereas at $50 \mathrm{mg} \mathrm{dm}^{-3}$ the mean was higher in treatments without the extract (Table 1). This is explained by the difference in the auxin concentrations when the Cyperus haspan extract and the humic substances are mixed at different concentrations. In the case of the fresh mass, the lowest concentration of humic substance combined with the extract may not have reached an auxin concentration capable of promoting a positive effect, while the opposite occurred in the case of H+-ATPase, where the highest concentration combined with the extract may have led to auxin concentrations so high that they became toxic.

Table 1: Mean fresh mass (FM) and H+-ATPase enzyme activity at each significant acid concentration, in the presence (WE) or absence (WoE) Cyperus haspan extract.

\begin{tabular}{ccccccc}
\hline & \multicolumn{2}{c}{$10\left(\mathrm{mg} \mathrm{dm}^{-3}\right)$} & \multicolumn{2}{c}{$25\left(\mathrm{mg} \mathrm{dm}^{-3}\right)$} & \multicolumn{2}{c}{$50\left(\mathrm{mg} \mathrm{dm}^{-3}\right)$} \\
\hline FM $(\mathrm{g})$ & $\begin{array}{c}\mathrm{H}^{+} \\
(\mathrm{U} / \mathrm{mL})\end{array}$ & $\mathrm{FM}(\mathrm{g})$ & $\begin{array}{c}\mathrm{H}^{+} \\
(\mathrm{U} / \mathrm{mL})\end{array}$ & $\mathrm{FM}(\mathrm{g})$ & $\begin{array}{c}\mathrm{H}^{+} \\
(\mathrm{U} / \mathrm{mL})\end{array}$ \\
\hline WoE & $1.153 \mathrm{a}$ & $0.995 \mathrm{~b}$ & $1.032 \mathrm{~b}$ & $1.063 \mathrm{~b}$ & $1.087 \mathrm{~b}$ & $1.393 \mathrm{a}$ \\
$\mathrm{WE}$ & $1.090 \mathrm{~b}$ & $1.177 \mathrm{a}$ & $1.075 \mathrm{a}$ & $1.256 \mathrm{a}$ & $1.126 \mathrm{a}$ & $1.354 \mathrm{~b}$
\end{tabular}

Means followed by the same letter in the column did not differ by the Scott-Knot test, $p<0.05$.

When analyzing the concentrations separately, the results were similar. When fulvic acid was used, the highest means were observed in the absence of the extract, except for the $50 \mathrm{mg} \mathrm{dm}^{-3}$ concentration. There are no previous reports on the effects of Cyperus haspan extract on H+-ATPase enzyme activity; however, in Arabica coffee it caused a slight increase in that activity. However, there are several reports showing increasing H+-ATPase activity when humic substances are used. In studies with coffee and maize species, the use of humic substances indicates the activation of the plasma membrane, more specifically $\mathrm{H}+$-ATPase, to be a possible metabolic marker that enables humic acid to actively participate in biological reactions (Façanha et al., 2002).

The mean fresh and dry mass at the $10 \mathrm{mg} / \mathrm{dm}^{3}$ concentration were higher in the presence Cyperus haspan extract and when treated with fulvic acid. At $50 \mathrm{mg} / \mathrm{dm}^{3}$, the fresh mass had a higher mean when treated with humic acid in the presence of the extract, and when treated with fulvic acid in the absence of the extract. The mean dry mass of the roots treated with humic acid was higher in the presence of the extract. When evaluating the effect of Cyperus haspan extract on the rhizogenesis of Solanum lycopersicum leaves, Souza et al. (2012) obtained satisfactory fresh and dry mass values for rhizogenesis and considering the use of the extract to be a promising organic treatment.

There was a linear increase in the H+-ATPase enzyme activity for humic acid in the absence of Cyperus haspan extract, but when the extract was added to the treatment it caused a quadratic increase at lower concentrations of humic acid. Fulvic acid, in both the presence and absence of extract, showed a slight quadratic increase (Figure 5). Considering these results for the enzyme, it is evident that its activity is more strongly promoted in treatments with humic acid. The extract affected the results only slightly, but with a positive and significant effect. Increases in $\mathrm{H}^{+}$-ATPase enzymes results in better efficiency of water use and nutrients, such as nitrogen (Azevedo, 2019).

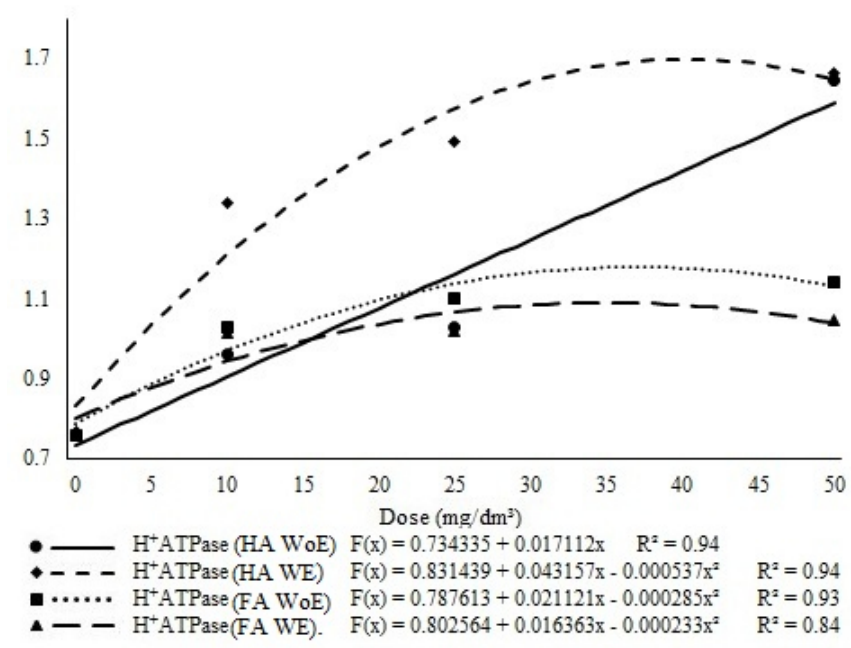

Figure 5: $\mathrm{H}+$-ATPase enzyme activity $(\mathrm{U} / \mathrm{mL})$ as a function of humic acid concentrations in the absence Cyperus haspan extract (HA WoE), humic acid concentrations in the presence Cyperus haspan (HA WE), fulvic acid concentrations in the absence Cyperus haspan extract (FA WoE), fulvic acid concentrations in the presence Cyperus haspan extract (FA WE).

Dias et al. 2012 did not find Cyperus haspan extract to be a viable alternative for inducing rooting when analyzing its use in the rooting of Robusta coffee cuttings, even with 
increased immersion times. In mofumbo, the extract was also not sufficient to promote the rooting of the cuttings (Oliveira et al., 2014), and the same effect was observed in golden dewdrop (Rezende; Zuffellato-Ribas; Koehler, 2013). However, for sugarcane the use of Cyperus haspan extract was very beneficial for rooting (Cruz Silva; Alves Neto; Viecelli, 2011)

Although Cyperus haspa has large quantities of IBA hormone in its leaves and roots, it also has many other constituents capable of producing negative allelopathic responses when in contact with some species (Andrade; Bittencourt; Vestena, 2009). That is one of the hypotheses for the fact that the extract did not have a strong effect on the parameters analyzed in this study.

The mean activities of catalase, superoxide dismutase and alcohol dehydrogenase were higher when in the presence Cyperus haspan extract compared to its absence. However, the mean esterase activity was higher in the absence of extract. In turn, in both the presence and absence of extract, humic acid led to statistically superior mean activities for catalase, superoxide dismutase and alcohol dehydrogenase, whereas for esterase, fulvic acid led to higher mean values in the cuttings, with and without Cyperus haspan extract.

These enzymes are important to help counteract the stress caused by reactive oxygen species, which can become very problematic in the process of seedling formation by vegetative propagation in coffee because they can cause lipid peroxidation in the plasma membrane, which can culminate in cell death and the death of the cutting. Among the reactive oxygen species, those that more strongly affect plants are the superoxide anion radical $\left(\mathrm{O}^{-}\right)$, the hydroxyl radical $\left(\mathrm{HO}^{-}\right)$ and hydrogen peroxide $\left(\mathrm{H}_{2} \mathrm{O}_{2}\right)$, which are produced by the disruption of metabolic pathways and by other normally functioning pathways (Andrade; Bittencourt; Vestena, 2009).

In the case of antioxidant enzymes, an increase in value is not indicative of improvement, but rather indicates that there is some type of stress in the environment, which may be due to the treatments used. For esterase, the lowest stress was observed for the treatment with humic acid in the absence of the extract. At the $25 \mathrm{mg} \mathrm{dm}^{-3}$ concentration, catalase, superoxide dismutase and alcohol dehydrogenase showed that the cuttings suffered less stress when using fulvic acid regardless of the presence or absence of extract, whereas for the esterase the same was observed in the treatment with humic acid and Cyperus haspan extract. At the $50 \mathrm{mg} \mathrm{dm}^{-3}$ concentration, the four enzymes expressed the lowest stress for the treatment with fulvic acid in the presence of extract, except for esterase for which lower stress was observed in the absence of extract. This was due to the various compounds present in the extract and in the humic substances, which can have other effects. In general, the treatments with fulvic acid and in the presence of Cyperus haspan extract showed the lowest stress.
Humic acids, especially when used with growthpromoting bacteria, are able to significantly alter metabolic fingerprints. The effects of biostimulants such as these stimulate primary and secondary metabolism in non-leguminous plants. In addition, they can be used to genetically manipulate metabolic pathways to aid plant breeding programs (Canellas; Olivares; Canellas, 2019).

Humic acids are soluble in alkaline media, and fulvic acids are soluble in alkaline and acidic media so regardless of the substrate $\mathrm{pH}$, fulvic acids will dissolve in the solution and be readily available for uptake by the plant. Fulvic acids have a low molecular weight, which facilitates their passage through the plasma membrane in the roots and thus can move within the plant and interact with or even influence its physiology and metabolism (Anjum et al. al., 2011). This means that foliar application rather than soil is a possible practice to improve the growth and nutrition of coffee seedlings, leading to improvements in leaf micronutrient accumulation (Justi; Morais; Silva, 2019).

Catalase, superoxide dismutase and alcohol dehydrogenase showed a decrease in activity with increasing humic acid concentrations in the treatments in absence Cyperus haspan extract until reaching a minimum value at approximately $30 \mathrm{mg} \mathrm{dm}^{-3}$. In contrast, esterase activity increased linearly with increasing humic acid concentration (Figure 6A). When using the Cyperus haspan extract in the treatment, there was almost no activity of the former three enzymes at the $10 \mathrm{mg} \mathrm{dm}^{-3}$ concentration, whereas the esterase activity decreased until the $25 \mathrm{mg} \mathrm{dm}^{-3}$ concentration, followed by a slight increase (Figure 6B). In the treatments with fulvic acid, both in the presence and absence of the extract the activity of catalase, superoxide dismutase and alcohol dehydrogenase were zero at approximately $20 \mathrm{mg} \mathrm{dm}^{-3}$. While the esterase activity oscillated, the lowest value was observed at $0 \mathrm{mg} \mathrm{dm}^{-3}$ in both situations (Figure 7). It was evident that the Cyperus haspan extract interacts with humic acid, leading to a decrease in the concentration of the acid. However, the interaction with fulvic acid was not as straightforward.

There are currently no studies of the effects Cyperus haspan extract on antioxidant enzymes, but it is known that aqueous and alcohol extracts of Cyperus haspan contain phenols that act directly on the indoleacetic acid (IAA) oxidase/peroxidase system of plants, regulating and inhibiting the oxidation of indoleacetic acid (Suzuki et al., 2012).

Reactive oxygen species are involved in various plant metabolic processes, including the regulation and development of plant growth and responses to biotic and abiotic stresses (Suzuki et al., 2012). The cutting process exerts a great stress on the cuttings, and humic substances have been shown to help mitigate the effects of this stress. To protect lipids from peroxidation, humic acids assist in the activation of antioxidant enzymes, helping to eliminate reactive oxygen species (García et al., 2014). 

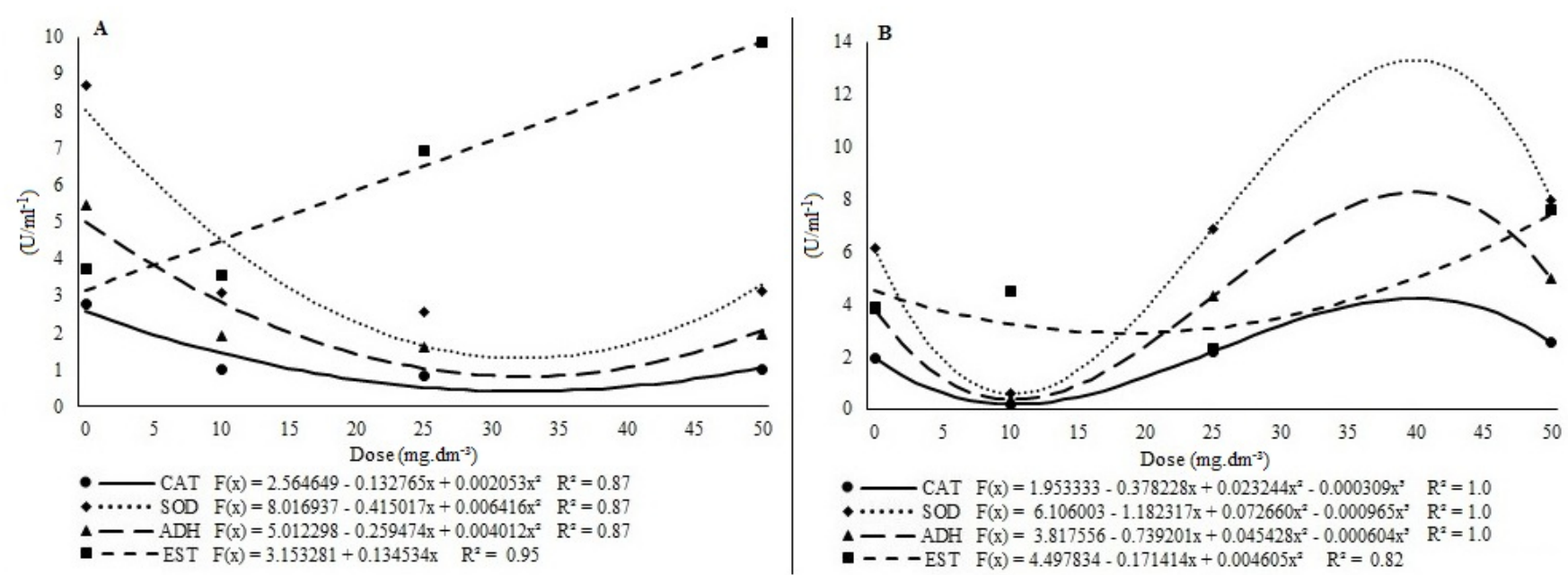

Figure 6: Activity of catalase (CAT), superoxide dismutase (SOD), alcohol dehydrogenase (ADH) and esterase (EST) according to the humic acid concentrations in absence C. haspan(A) and presence Cyperus haspan extract (B).
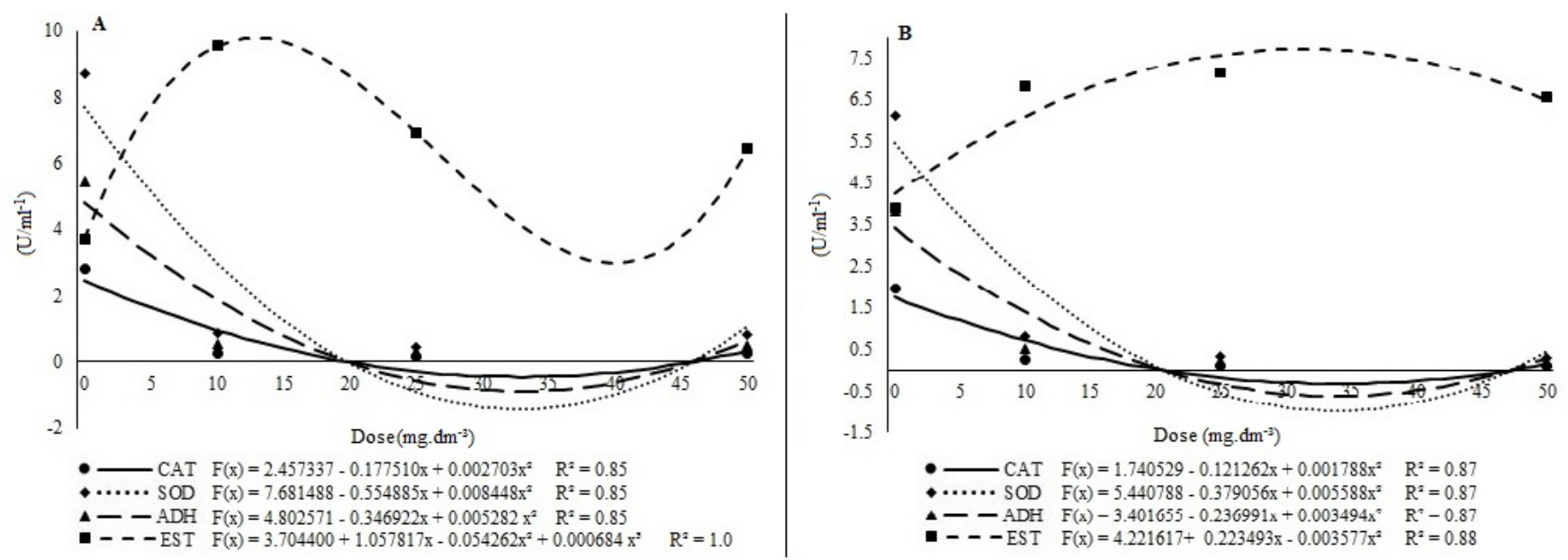

Figure 7: Activity of catalase (CAT), superoxide dismutase (SOD), alcohol dehydrogenase (ADH) and esterase (EST) according to the fulvic acid concentrations in absence $C$. haspan $(A)$ and presence $C$. haspan extract $(B)$.

\section{CONCLUSIONS}

There is a higher rooting rate of Arabica coffee cuttings when they are treated with humic acid at $10 \mathrm{mg} \mathrm{dm}^{-3}$ in the presence Cyperus haspan extract.

Further analysis and studies on the use of Cyperus haspan extract and humic substances in the Arabica coffee crop are needed to obtain more conclusive results.

\section{ACKNOWLEDGEMENTS}

We would like to thank the Federal University of Lavras, the Department of Agriculture, the Agência de Inovação do Café (Coffee Innovation Agency), the Núcleo de estudos em melhoramento e clonagem (Breeding and Cloning Research Center - NEMEC), the Seed Sector and its employees, and the Brazilian Federal Agency for the Support and Evaluation of Graduate Education (CAPES).

\section{REFERENCES}

ALFENAS, A. C. Eletroforese e marcadores bioquímicos em plantas e microrganismos, 2.ed. Viçosa: Ed. da UFV, 627 p, 2006.

ANDRADE, H. M. et al. Potencial alelopático de Cyperus rotundus L. sobre espécies cultivadas. Ciência e Agrotecnologia, 33(Edição especial):1984-1990, 2009.

ANJUM S. A. et al. Fulvic acid application improves the maize performance under well-watered and drought conditions. Journal of Agronomy and Crop Science, 197(6):409-417, 2011.

AZEVEDO, I.G. et al. Humic acids and Herbaspirillum seropedicae change the extracellular $\mathrm{H}+$ flux and gene expression in maize roots seedlings. Chemical and Biological Technologies in Agriculture, 6(8):1-10, 2019. 
BRADFORD, M. M. A rapid and sensitive method for the quantitation of microgram quantities of protein utilizing the principle of protein-dye binding. Analytical Biochemistry, 72(1-2):248-54, 1976.

CANELLAS, L. P. et al. Humic acids increase the maize seedlings exudation yield. Chemical and Biological Technologies in Agriculture, 6(3):1-14, 2019.

CANELLAS, L. P. et al. Probing the hormonal activity of fractionated molecular humic components in tomato auxin mutants. Annals of Applied Biology, 159(2):202-211, 2011.

CANELLAS, N. O. A.; OLIVARES, F. L.; CANELLAS, L. P. Metabolite fingerprints of maize and sugarcane seedlings: searching for markers after inoculation with plant growthpromoting bacteria in humic acids. Chemical and Biological Technologies in Agriculture, 6(14):1-10, 2019.

CARVALHO, M. et al. Comportamento em condições de campo de cafeeiros (Coffea arabica L.) propagados vegetativamente e por semeadura. Coffee Science, 3(2):108-114, 2008.

CASIMIRO, I. et al. Dissecting Arabidopsis lateral root development. Trends in Plant Science, 8(4):165-171, 2003.

CRUZ SILVA, C. T. A.; ALVES NETO, A. J.; VIECELLI, C. A. Extratos aquosos de tiririca sobre o enraizamento de cana-de-açúcar. Varia Scientia - Agrárias (Online), 2(1):49-61, 2011.

DIAS, J. R. M. et al. Enraizamento de estacas de cafeeiro imersas em extrato aquoso de tiririca. Coffee Science, 7(3):259-266, 2012.

FAÇANHA, A. R. et al. Bioatividade de ácidos húmicos: Efeitos sobre o desenvolvimento radicular e sobre a bomba de prótons da membrana plasmática. Pesquisa Agropecuária Brasileira, 37(9):1301-1310, 2002.

FERREIRA, D. F. Sisvar: A guide for its bootstrap procedures in multiple comparisons. Ciência e Agrotecnologia, 38(2):109-112, 2014.

FERREIRA, G. et al. Enraizamento de estacas de atemoieira 'gefner' tratadas com auxinas. Revista Brasileira de Fruticultura, 30(4):1083-1088, 2008.

GARCÍAA. C. et al. Potentialities of vermicompost humic acids to alleviate water stress in rice plants (Oryza sativa L.). Journal of Geochemical Exploration, 136:48-54, 2014.

GEISS, G.; GUTIERREZ, L. E BELLINI, C. Adventitious root formation: New insights and perspectives. Annual Plant Reviews, 37:127-156, 2009.
GIANNOPOLITIS, C. N. et al. Superoxide dismutases. I. Occurrence in higher plants. Plant Physiology, 59:309314, 1977.

HARTMANN, H. T. et al. Plant propagation: Principles and practices. Ed. 8, New Jersey: Prentice Hall 915p. 2011.

HAVIR, E. A.; MC HALE, N. A. Biochemical and developmental characterization of multiple forms of catalase in tobacco leaves. Plant Physiology, 84(2):450$455,1987$.

JINDO, K. et al. Root growth promotion by humic acids from composted and non-composted urban organic wastes. Plant Soil, 353:209-220, 2012.

JORGE, L. A. C. de.; RODRIGUES, A. F. de O. Safira: Sistema de análise de fibras e raízes. Boletim de pesquisa e desenvolvimento EMBRAPA. São Carlos, 2010, 20p.

JUSTI, M.; MORAIS, E. G.; SILVA, C. A. Fulvic acid in foliar spray is more effective than humic acid via soil in improving coffee seedlings growth. Archives of Agronomy and Soil Science, 65(14):1-15, 2019.

LORENZI, H. Plantas daninhas do Brasil: Terrestres, aquáticas, parasitas e tóxicas. 3. ed. Nova Odessa: Instituto Plantarum, 2000, 608p.

MORARD, P. et al. Direct effects ofhumic-like substance ongrowth, water, and mineral nutrition of various species. Journal of Plant Nutricion, 34(1):46-59, 2011.

NARDI, S. et al. Biological activities of humic substances. In: SENESI, N.; XING, B.; HUANG, P. M. (eds) Biophysico-chemical processes involving natural nonliving organic matter in environmental systems. Wiley, Hoboken, p 305-339, 2009.

OLIVEIRA, D. H. et al. Influência do comprimento de estacas e ambientes, no crescimento de mudas cafeeiras obtidas por enraizamento. Coffee Science, 5(2):183-189, 2010 .

OLIVEIRA, D. M. et al. Estaquia para propagação vegetativa do mofumbo. Revista Verde, 9(1):163-167, 2014.

PALMGREN, M. G. Plant plasma membrane H+-ATPases: Powerhouses for nutrient uptake. Annual review of plant physiolgy and plant molecular biology, 52(6):817-845, 2001.

PEREIRA, F. A. C. et al. Selection of Coffea arabica L. hybrids using mixed models with different structures of variance-covariance matrices. Coffee Science, 13(3):304$311,2018$. 
PINTON, R. et al. Modulation of $\mathrm{NO}_{3}^{-}$uptake by waterextractable humic substances: involvement of root plasma membrane $\mathrm{H}^{+}$-ATPase. Plant and Soil, 215:155-161, 1999

REZENDE, F. P. F.; ZUFFELLATO-RIBAS, K. C.; KOEHLER, H. S. Aplicação de extratos de folhas e tubérbulos de Cyperus rotundus L. e de auxinas sintéticas na estaquia caulinar de Duranta repens L. Revista Brasileira de Plantas Medicinais, 15(4):639645, 2013.

REZENDE, T. T. et al. Propagação vegetativa do cafeeiro (Coffea arabica L.) por miniestacas. Coffee Science, 12(1):91-99, 2017.

RONCATTO, G. et al. Enraizamento de estacas de espécies de maracujazeiro (Passiflora spp.) no inverno e no verão.
Revista Brasileira de Fruticultura, 30(4):1089-1093, 2008.

SOUZA, M. F. et al. Efeito do extrato de Cyperus rotundus na rizogênese. Revista de Ciências Agrárias, 35(1):157162, 2012.

SUZUKI N. et al. ROS and redox signaling in the response of plants to abiotic stress. Plant, Cell \& Environment, 35(2):259-270, 2012

TREVISAN, S. et al. Humic substances biological activity at the plant-soil interface. Plant Signaling \& Behavior, 5(6):635-643, 2010.

VAN OVERBEEK, J. et al. An analysis of the function of the leaf in the process of root formation in cuttings. American Journal of Botany, 33(2):100-107, 1946. 